Kapata Arkeologi, 12(2), 147-162

ISSN (cetak): 1858-4101

ISSN (elektronik): 2503-0876

http://kapata-arkeologi.kemdikbud.go.id

\title{
POLA PERMUKIMAN TRADISIONAL KAJANG ${ }^{1}$ \\ Traditional Settlement Patterns of Kajang
}

\author{
Erni Erawati \\ Universitas Gadjah Mada - Indonesia \\ Program Doktor Ilmu-Ilmu Humaniora Fakultas Ilmu Budaya UGM \\ erni_lewa@yahoo.com
}

Naskah diterima: 14/09/2016; direvisi: 23/11 - 06/12/2016; disetujui: 06/12/2016

Publikasi ejurnal: 30/12/2016

\begin{abstract}
One of traditional settlements in Indonesia is located in the residential area of Kajang, Bulukumba, South Sulawesi Province. Settlement community in Kajang is classified into two levels, the first is meso level consisted on spatial villaes, homes, and forest, and the second is macro level consisted on the spatial region consisting of kamase-masea region, and the region kuassayya. From the shape and function of artefacts and sites in Kajang area, it can be mentioned that the Kajang district has the Megalithic sites and Islamic sites which are still functioned until recently. The aim of this research is determining the pattern of settlement in the area of the Kajang based on the location of the sites. The source of data consist of two namely secondary data which is obtained from literary research, and primary data obtained through field research by observation and survey. The pattern of settlement in the Kajang area shows two characteristics; firstly, Settlement patterns and placement of home in group, leading to the altitude, facing to the west; the sacred building that is located at high altitude and surrounded by indigenous forest areas and settlers houses. Secondly, settlement patterns extend lengthwise in a row on both sides of a pathway up to the foothills, and on riverbanks. Those houses are characterised by the location of owner's social stratification. There is no specific orientation of houses to the wind directions. Sacred building is placed in higher space surrounded by residents' houses. Ammatoa as the spiritual leader, and a site that functions to inaugurate Karaeng as leaders of the governance.
\end{abstract}

Keywords: Patterns, Settlement, Traditional, Function, Sites

\section{Abstrak}

Salah satu permukiman tradisional di Indonesia adalah permukiman di kawasan Kajang, Kabupaten Bulukumba, Propinsi Sulawesi Selatan. Permukiman masyarakat di kawasan Kajang terdiri atas dua tingkat, yaitu bersifat meso yang menyangkut tata ruang desa, rumah tinggal, dan hutan adat, dan bersifat makro menyangkut tata ruang kawasan yang terdiri atas kawasan kamase-masea dan kawasan kuassayyya. Dari bentuk dan fungsi situs-situs di kawasan Kajang, dapat dikatakan bahwa kawasan Kajang memiliki situs Megalitik dan situs Islam yang masih dipergunakan sampai sekarang. Penelitian bertujuan untuk mengetahui pola permukiman di Kawasan Kajang berdasarkan letak situs-situs. Sumber data penelitian ada dua, yaitu data sekunder yang diperoleh melalui penelitian pustaka, dan data primer diperoleh melalui penelitian lapangan dengan cara observasi dan survei permukaan.Pola permukiman di kawasan Kajang menampilkan dua ciri, yaitu: 1). Pola permukiman dan penempatan rumah secara berkelompok mengarah pada ketinggian, arah hadap rumah ke arah barat, bangunan sakral berada di tempat ketinggian dan dikelilingi oleh kawasan hutan adat dan bangunan rumah penduduk, 2). Pola permukiman berbentuk memanjang dan berderet disebelah menyebelah jalan, kaki bukit, dan pinggir sungai dan pantai dengan ciri yang menunjukkan pelapisan sosial. Terdapat dua fungsi situs di kawasan Kajang, yaitu: situs yang berfungsi sebagai tempat pelantikan Ammatoa sebagai pemimpin di bidang spiritual, dan tempat pelantikan Karaeng yang dianggap pemimpin di bidang pemerintahan.

Kata kunci: Pola, Permukiman, Tradisional, Fungsi, Situs

${ }^{1}$ Artikel ini merupakan bagian dari disertasi dengan judul "Tata Ruang Permukiman Tradisional To Kajang Di Kabupaten Bulukumba Propinsi Sulawesi Selatan: Kajian Sistem Sosial dan Nilai Budaya”. 


\section{PENDAHULUAN}

Kawasan Kajang merupakan kawasan tradisional yang berada di Kecamatan Kajang Kabupaten Bulukumba, Propinsi Sulawesi Selatan. Pola permukiman ditandai dengan penduduk yang bertempat tinggal di suatu wilayah yang berada di perbukitan pinggir pantai Teluk Bone, berhadapan dengan Pulau Selayar, $\pm 154 \mathrm{~km}^{2}$ sebelah tenggara Kota Makassar. Luas Kecamatan Kajang 129,06 km² terdiri atas perkampungan seluas $47 \mathrm{Ha}$, sawah $1.746,48 \mathrm{Ha}$, ladang 6.028,91 $\mathrm{Ha}$, dan lain-lain $54 \mathrm{Ha}$, luas hutan seluruhnya berdasarkan data yang ada, ialah $275 \mathrm{Ha}$ dengan perincian; hutan Cangpakapuang $175 \mathrm{Ha}$, dan hutan adat 100 Ha. Mata pencaharian penduduk adalah pertanian, terutama menghasilkan jagung. Jumlah penduduk Kajang $\pm 40 \%$ penganut kepercayaan patuntung, dan sering disebut kelompok masyarakat pakaian hitam. Meskipun demikian, mereka mengaku beragama Islam. Istilah patuntung berasal dari kata tuntungi, kata dalam bahasa Makassar yang jika diterjemahkan ke dalam bahasa Indonesia berarti "mencari sumber kebenaran". Kepercayaan patuntung mengajarkan jika manusia ingin mendapatkan sumber kebenaran, maka ia harus menyandarkan diri pada tiga pilar utama, yaitu menghormati Turie A'Ra'na (Tuhan Y.M.E), tanah yang diberikan Turie $A^{\prime} R a$ 'na, dan nenek moyang (Rossler, 1990). Kepercayaan dan penghormatan terhadap Turie $A^{\prime} R a$ 'na merupakan keyakinan yang paling mendasar dalam kepercayaan patuntung. Masyarakat Kajang percaya bahwa Turie A'Ra'na adalah pencipta segala sesuatu, Maha Kekal, Maha Mengetahui, Maha Perkasa, dan Maha Kuasa.

Masyarakat Kajang terdiri atas dua kelompok yang secara adat masuk ke dalam wilayah ipantarang embayya, dan wilayah ilalang embayya, yaitu: 1) Kelompok masyarakat kuassayya, yaitu meliputi Desa Mattoanging, Desa Possi Tanah, Desa Tambangan, Desa Lembanna, Desa Bontorannu, Desa Lembang, Kelurahan Tanah Jaya, dan 2) Kelompok masyarakat kamasemasea, berada di Desa Batu Nilamung, Desa Sapanang, Desa Pattiroang, Desa Malleleng, dan Desa Tanah Toa. Kedua kelompok masyarakat ini masih berpegang teguh pada ajaran nenek moyang, meskipun ada usaha penyesuaian dengan ajaran Islam sebagaimana dipraktekkan oleh sebagian penduduk, tetapi ajaran Islam masih belum mendalam, sehingga tidak seluruh rukun Islam dapat mereka hayati. Dengan mempergunakan media peninggalan megalitik dan Islam, masyarakat melakukan upacara ritual dan berusaha mengamalkan nilainilai moral dan kerohanian berdasarkan ajaran "pasang" yang merupakan ajaran leluhur mereka. Ajaran inilah yang jadi pedoman kedua kelompok masyarakat dan pemimpin di Kajang dalam kehidupan sehari-hari.

Sistem budaya masyarakat masa lalu terdiri atas aktifitas yang dilakukan dalam perjalanan hidup mereka sehari-hari. Sistem sosial meliputi pranata-pranata atau kelompok sosial yang diorganisasi untuk tujuan penyelenggaraan berbagai aktifitas. Sistem ekologi terdiri atas adaptasi manusia terhadap lingkungan dan penggunaan sumber daya alam yang terdapat di suatu lokasi (Rouse, 1972: 95). Nilai-nilai budaya masyarakat Kajang, salah satunya dapat dijelaskan berdasarkan pola pemukiman tradisional yang masih bertahan hingga kini, yang diwariskan dari leluhur. Menurut Butzer (1982: 243), pola permukiman mengalami perkembangan sesuai dengan keadaan masyarakatnya. Permukiman tradisional yang sederhana dan berukuran kecil kemudian berevolusi menjadi permukiman kerajaan yang semakin kompleks, luas dan padat. Apalagi, jika permukiman tradisional telah menjadi perkotaan akan semakin kompleks. Meskipun kehidupan perkotaan kini semakin berkembang, namun ada pula sistem permukiman tradisional yang masih bertahan. Ciri yang menonjol pada masyarakat tradisional adalah adanya aspek yang dikeramatkan, baik berupa benda maupun tempat yang menjembatani antara mereka dengan yang dianggap suci dan keramat. Menurut Catanese dan Snyder, setiap kebudayaan tradisional selalu memperlihatkan suatu aturan suci, mulai dari rumah sampai ke permukiman dan keseluruhan lingkungan. Dengan demikian, maka upaya untuk memahami permukiman tradisional menuntut agar permukimanpermukiman dipandang sebagai perwujudan ruang yang suci (Catanene dan Snyder, 1986:50).

Dalam penelitian ini akan dilihat bagaimana masyarakat yang masih hidup dalam permukiman tradisional, dalam hal ini kawasan Kajang, menjaga dirinya dari berbagai pengaruh 
atau intervensi dari luar. Salah satu caranya adalah menjaga dan menerapkan "pesan dan filosofi" dari nenek moyang mereka dalam kehidupan keseharian, pesan dan filosofi itu tertuang didalam ajaran "pasang ri Kajang". Artinya, "pasang" adalah pesan-pesan, wasiat atau amanat. "ri" merupakan kata perangkai yang menunjukkan tempat atau "di". Kata Kajang adalah nama suatu komunitas, yang sekarang juga dipakai untuk menamai wilayah administrasi kecamatan, tempat sebagian besar komunitas itu hidup. Jadi secara harfiah ungkapan pasang ri Kajang berarti pesan-pesan di Kajang (Katu, 2008: 1). Bagi masyarakat Kajang, pesan-pesan dimaknai sebagai tuntutan atau amanah, renungan atau ramalan. Selain itu, dapat berarti peringatan atau mengingat. Bagi mereka, pasang menjadi kerangka acuan dalam pola interaksi antar komunitas, baik pola hubungan vertikal maupun horizontal. Bertolak dari uraian tersebut di atas, maka permasalahan yang ingin dikaji adalah "Bagaimana pola permukiman di kawasan Kajang berdasarkan keletakan situs-situs?" Tujuan penelitian adalah menggambarkan pola permukiman untuk dapat merekonstruksi kebudayaan, struktur sosial, dan lingkungan dengan memandang masing-masing unsur tersebut sebagai satuan sistem yang tidak terpisahkan.

\section{METODE}

Penelitian yang penulis lakukan di kawasan Kajang menggunakan daftar desa/kelurahan yang dianggap bisa membantu pelacakan situs atas dasar nama desa/kelurahan, yaitu yang diterbitkan oleh kantor statistik 2010, dan peta rupa bumi tahun 1925 yang diterbitkan oleh U.S Army. Situs-situs dalam penelitian ini diberi nama sesuai dengan nama desa, dusun atau nama orang untuk situs makam. Nama-nama "tempat" dalam kawasan Kajang yang disebutkan dalam pasang (tradisi lisan masyarakat Kajang) yang selanjutnya disebut "situs" ada yang dapat dipakai sebagai pedoman untuk menemukan kembali lokasi tempat-tempat tersebut, ada juga yang tidak dapat dipakai.

Pola pemukiman dapat dianggap sebagai ekspresi dari konsepsi manusia mengenai ruang serta merupakan hasil dari upaya manusia untuk mengubah dan memanfaatkan lingkungan fisiknya berdasarkan atas pandanganpandangan dan pengetahuan yang dimilikinya mengenai lingkungan tersebut (Ahimsa-Putra , 1995: 14). Bagi Rouse (1972: 96) pola permukiman adalah kajian tentang cara-cara distribusi aktivitas-aktivitas budaya manusia dan pranata-pranata sosialnya keseluruh kawasan. Pola semacam itu, dapat mencerminkan sistem budaya, sistem sosial, atau sistem ekologi, bahkan juga merupakan cerminan kaitan-kaitan antara ketiga sistem tersebut. Didasarkan pada pengertianpengertian di atas, secara lebih singkat dapat dirangkum bahwa pola permukiman (settlement patterns) merupakan wujud dari tata cara manusia dalam mengatur diri untuk bertempat tinggal dalam lingkungan tempat mereka hidup (Willey, 1953: 11) yang di dalamnya terdapat unsur-unsur tempat tinggal dan relasinya dengan ekologi tertentu, termasuk kondisi geografi dan fisiografi, sistem pengetahuan maupun pranata sosial tertentu.

Kajian arkeologi permukiman dalam dekade terakhir mulai berkembang mengikuti paradigma baru dalam arkeologi pada umumnya yaitu lebih cenderung mengikuti cara pikir pasca-prosesual (post-processual). Rob Wiseman (2016), misalnya, menyatakan bahwa unsur-unsur permukiman seringkali dilihat sebagai metafora dari sesuatu yang lain. Artinya, unsur-unsur permukiman itu sebenarnya mewakili unsur budaya yang lain. Misalnya, metafora itu diungkapkan dalam pernyataan "jarak sosial adalah jarak fisik" (social distance is physical distance). Dalam permukiman hal itu diwujudkan dalam keletakan setiap tempat atau rumah, sehingga jarak rumah mencerminkan jarak hubungan kekerabatan. Rumah kerabat dekat raja letaknya akan lebih dekat ke kraton tempat raja tinggal jika dibanding letak rumah kerabat jauh. Dengan kata lain, semakin dekat rumah seseorang dengan kraton, semakin dekat pula hubungan kekerabatannya dengan raja. Metafora lain terkait unsur permukiman juga ditunjukkan dari pernyataan seperti "kubur adalah rumah" pada masyarakat menetap, "hutan adalah kehidupan" bagi masyarakat pemburu-peramu, atau "bekal kubur adalah pribadi yang dikuburkan." Dengan cara pikir itu, Wiseman (2016: 2-4) meyakini bahwa dengan memetakan bukti-bukti aktivitas atau data arkeologi dalam permukiman akan dapat terbaca juga jejaring hubungan sosial yang ada. 


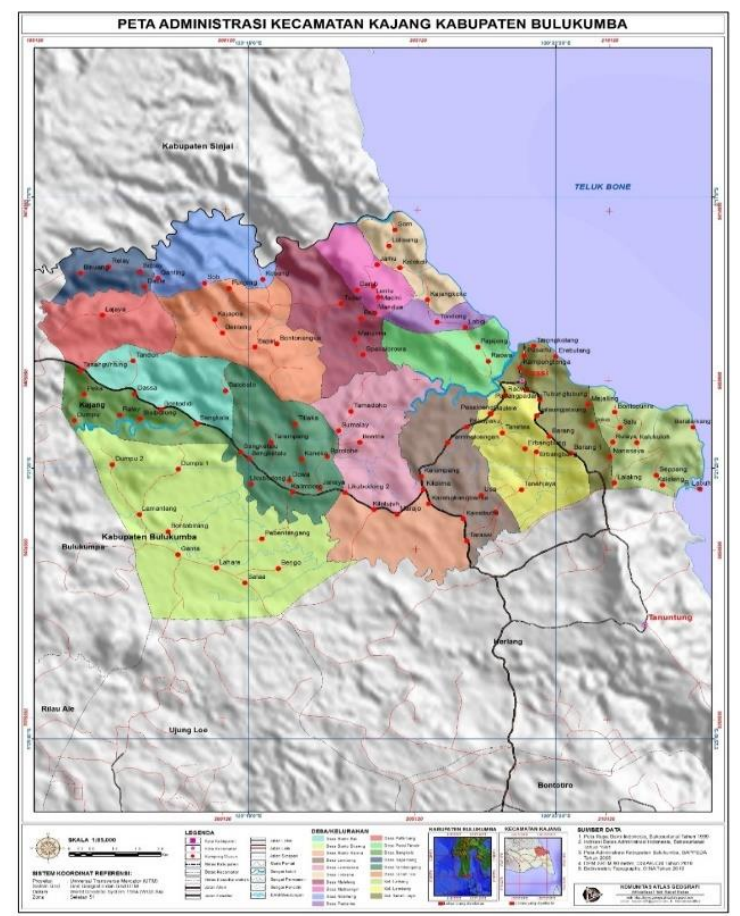

Gambar 1. Peta Kecamatan Kajang Kabupaten Bulukumba Sulawesi Selatan

\section{HASIL DAN PEMBAHASAN}

Berdasarkan data hasil penelitian, permukiman dapat didefenisikan sebagai sebuah hasil gagasan, dan tindakan manusia yang dirancang sedemikian rupa sehingga mencerminkan keputusan, pilihan, dan cara manusia melakukan adaptasi secara spesifik. Nilai, norma, kriteria, dan asumsi tertentu dipergunakan dalam menentukan pilihan terhadap hal-hal yang terkait dengan permukiman. Pilihan-pilihan tersebut dapat digambarkan dalam skema sederhana (Rapoport, 1986: 44-45).

Pola yang terdapat pada permukiman tradisional yang berlangsung mulai pada masa prasejarah berhubungan dengan kepercayaan yang dianut oleh pendukungnya. Hal ini didasari oleh kepercayaan berupa kepercayaan animisme dan kepercayaan dinamisme yang mendominasi kehidupan pendukungnya, sehingga segala sesuatu yang berhubungan dengan permukiman seperti upacara dan ritus yang ada mengikuti aturan dalam kepercayaan mereka. Hal ini bisa dilihat melalui hasil penelitian dari beberapa arkeolog yang mengkaji keletakan beberapa situs permukiman, diantaranya Situs Megalitik Pasemah (Sumatera Selatan) berkaitan dengan Gunung Dempo (Hoop, 1932), Megalitik Cirebon dan Kuningan berkaitan dengan Gunung Cerme (Soejono, 1993, Heekern, 1972), Megalitik Bali berkaitan dengan Gunung Agung. Hal tersebut merupakan sebuah bukti bahwa keletakan dalam permukiman prasejarah merupakan sesuatu yang terpola oleh gagasan dari pendukung budaya tersebut yang didasarkan pada kepercayaan yang dinyakini pada masa itu.

Permukiman di kawasan Kajang terdiri atas beberapa variabel permukiman yang kesemuanya merupakan perwujudan dari masyarakat yang taat pada ketetapan yang telah digariskan oleh Tau Rie' A'rana (Tuhan YME) kepada mereka melalui pasang. Temuan yang terdapat di situs-situs di kawasan Kajang meliputi: rumah tradisional, pagar batu, sumur, batu pannurungang, batu temu gelang, batu pemujaan, batu datar, batu pelantikan, batu bergores, batu berlubang, menhir, dolmen, batu dakon, dan makam, hutan adat, dan sebaran keramik. Potensi sumber daya lingkungan fisik situs dapat dilihat seperti sungai, sumur sebagai potensi penyediaan air untuk kehidupan manusia, hutan sebagai potensi tempat penyelenggaraan upacara, penampang topografi situs berupa bukit sebagai sarana penyaluran konsep ideologi masyarakat yang berkaitan dengan latar belakang kepercayaannya.

Diantara semua yang disebutkan di atas, apabila ditinjau dari segi konteks dan asosiasinya, menunjukkan satu kesatuan fungsional yang berciri dan berorientasi religi, lebih khusus lagi pemujaaan. Di samping fungsi dan peranan dalam konteks hubungan antartemuan, terlihat pula bahwa kecenderungan penilaian itu didasarkan pada keletakan dan orientasinya. Gagasan utama yang diperlihatkan disini adalah adanya kesengajaan menempatkan keseluruhan temuan pada suatu tempat ketinggian (puncak bukit) dengan orientasi mengarah pada mata angin (orientasi kosmis), yaitu ke arah barat, suatu konsepsi yang lazim dalam tradisi masyarakat megalitik oleh karena salah satu kepercayaan pada tradisi ini adalah bahwa roh nenek moyang atau dewa bersemayam di puncak gunung, yang bagi suatu masyarakat yang memiliki gejala ini mempersonifikasikan gunung dalam bentuk mikro berupa bangunan teras berundak.

Fungsi situs dapat diketahui berdasarkan fungsi jenis temuan yang terdapat di dalamnya (artefak dan fitur), serta perilaku masyarakat 
pengguna temuan tersebut. Berdasarkan fungsi dari artefak dan fitur sebagai data arkeologi dapat dikategorikan atas tiga yakni: 1). Teknofak, 2). Sosiofak, dan 3). Ideofak (Sharer dan Ashmore, 1979: 59). Menurut Brian M.Fagan, bahwa berdasarkan fungsinya, maka situs dapat dikategorikan sebagai situs pemukiman, situs pembantaian, situs penguburan, situs upacara keagamaan, situs perdagangan, situs pertambangan, dan lain-lain (Fagan, 1985: 78). Berdasarkan hasil analisis fungsi terhadap masing-masing jenis temuan yang terdapat pada masing-masing situs di atas, maka fungsi situs dapat diketahui. Bentuk atau karakter yang nampak di situs-situs di kawasan Kajang dicirikan oleh tradisi Megalitik dan Islam.

Situs megalitik di kawasan Kajang memiliki ciri umum sebagai berikut: 1). Tata letak menempati area ketinggian, 2). Setiap komponennya merupakan satu kesatuan fungsional, dan 3). Berkaitan dengan keletakannya, dapat dipastikan bahwa objek digunakan dalam rangka aktivitas pemujaan atau penghormatan kepada oknum tertentu, dalam hal ini tradisi megalitik yang muncul setelah tradisi bercocok tanam mulai meluas, tak ketinggalan terus menerus ikut menghayati corak budaya yang masuk ke Indonesia. Tradisi megalitik meluas di Indonesia tidak lain disebabkan oleh adanya suatu proses migrasi dan difusi budaya yang telah berlangsung sangat lama dan intensif. Menurut Soejono (1977: 278), dibeberapa tempat di Indonesia masih dijumpai sebagian masyarakat menjalankan aktivitas prasejarah, hal ini disebabkan letak pulau-pulau berserakan. Di pihak lain ada beberapa daerah di mana hidup kepurbaan berlangsung terus bersamaan dengan ciri-ciri masa yang paling baru, seperti tampak di kawasan Kajang saat ini.

Sisa-sisa tradisi megalitik di Indonesia mempunyai daerah persebaran yang sangat luas seperti di daerah Nias, Toraja, dan Flores khususnya Indonesia Timur (Geldern, 1945: 129). Pendapat ini diperkuat oleh Van Heekeren yang menyebutkan bahwa di beberapa tempat di Indonesia tradisi megalitik masih berlangsung dan berkembang dengan baik sampai sekarang (Heekeren, 1958: 73). Situssitus megalitik di kawasan Kajang menunjukkan adanya pergeseran fungsi dari konteks masa lalu ke masa sekarang. Perilaku yang masih dapat diamati sampai sekarang, menunjukkan bahwa keterkaitan manusia dengan gejala alam merupakan sesuatu yang terintegralistik dan tidak dapat dipisahkan satu sama lain. Tinggalan yang berciri pemujaan pada situs megalitik di kawasan Kajang dapat dilihat dalam dua konteks, yaitu dalam konteks perilaku (konteks sistem) dan konteks arkeologi. Konteks perilaku, yaitu adanya kenyataan masih digunakannya beberapa media artefak sebagai sarana upacara dan pemujaan sebagai aktualisasi diri bagi masyarakat yang masih mempercayai keampuhan dan keberkahan benda tersebut. Dalam hal ini media tersebut dijadikan sebagai tempat pemberian sesajian dan tempat upacara pelantikan. Elemen situs yang berperan dalam hal ini adalah batu datar, dolmen, batu pannurungang ${ }^{2}$, dan batu pelantikan. Konteks arkeologi, yaitu adanya kenyataan bahwa sebagian dari elemen tersebut tidak digunakan lagi yaitu batu bergores, dan menhir.

Perlakuan bernafaskan religi dan pemujaan yang berlangsung pada situs-situs di kawasan ini dalam bentuk pemberian sesaji yang diletakkan di atas tumpukan batu/dolmen (altar) dengan harapan dapat terpenuhinya maksud dan hasrat mereka. Sesaji adalah bentuk perilaku tertua yang masih dapat disaksikan sampai sekarang. Maknanya adalah sebagai simbol dan pernyataan tunduk dan patuh kepada "sesuatu" yang dipuja atau disembah yang wujudnya dapat berupa arwah leluhur atau nenek moyang atau bahkan dewa. Pada sebagian besar masyarakat BugisMakassar, pernyataan taat dan tunduk pada individu-individu ini dapat dilihat sebagai bagian dari sistem religi leluhur mereka yang disebut attoriolong (Bugis)/ pattauriolong (Makassar). Masyarakat Bugis-Makassar masa lampau juga percaya pada kekuatan gaib yang datang dari dewa yang meliputi Dewa Langi, Dewa MallinoE, dan Dewata SeuwaE sebagai dewa utama. Di samping itu, masih ada pula kepercayaan masyarakat akan animisme dan dinamisme. Menurut teori mengenai bersaji, bahwa pada upacara seperti itu, manusia menyajikan sebagian dari seekor binatang terutama darahnya kepada dewa, kemudian memakan sendiri sisa daging dan darahnya,

${ }^{2}$ Pannurungang=tempat turun. Oleh masyarakat setempat Batu Pannurungang dianggap sebagai tempat turunnya Ammatoa 1. 
oleh Robertson Smith dianggap sebagai suatu aktifitas untuk mendorong rasa solidaritas dengan dewa. Dalam hal itu dewa atau para dewa dipandang juga sebagai warga komunitas, walaupun sebagai warga yang istimewa. Dalam contoh-contoh etnografis yang diajukan sebagai ilustrasi dari gagasannya, Robertson Smith menggambarkan upacara bersaji sebagai suatu upacara yang gembira dan meriah tetapi juga keramat, dan tidak sebagai suatu upacara yang hikmad dan keramat (dalam Koentjaraningrat, 1987:68). Berdasarkan pendapat tersebut, maka dapat disimpulkan bahwa upacara bersaji bukanlah dominasi bagi sekelompok etnik dan kawasan tetapi gejalanaya meluas di berbagai kawasan dunia.

Perilaku yang memperlihatkan tandatanda religi di Indonesia telah ada pada masa prasejarah, yaitu masa mesolitik dengan konsepsi politeisme dan mencapai perkembangannya di masa neolitik dan logam (perundagian) yang bersamaan dengan tumbuhnya satu corak budaya yang religius yaitu megalitik (pemujaan arwah leluhur) (Soejono, 1976: 16). Jejak-jejak itu masih dapat disaksikan sampai sekarang di berbagai daerah di Indonesia. Perubahan fungsi dan peranan bagi objek-objek pemujaan yang diperlihatkan situs-situs megalitik yang terdapat di kawasan Kajang dasarnya bersumber dari kenyataan bahwa tidak ada satu pun kebudayaan di dunia yang terbebas intervensi dari luar lingkunganya, seketat apapun pranata itu dipelihara dan diawasi. Jadi adanya pergeseran fungsi harus dilihat sebagai suatu konsekuensi logis, meskipun pada substansinya tetap ada yaitu penggunaan media sebagai sarana aktualisasi diri dalam berhubungan dengan oknum yang disembah atau dipuja.

Situs Islam di kawasan Kajang memiliki ciri umum sebagai berikut: 1) Berada pada tempat ketinggian, 2) Terdapat keberlanjutan dan perpaduan budaya, 3) Setiap komponennya merupakan satu kesatuan, 4) Berkaitan dengan keletakannya, dapat dipastikan bahwa objek ditujukan untuk penghormatan kepada oknum tertentu, 5) Terdapat dua orientasi makam dalam satu kompleks makam, 6) Pada nisan umumnya tidak terdapat tulisan sebagai penanda siapa yang dimakamkan.

Fungsi dan kedudukan situs-situs di kawasan Kajang akan dijelaskan berdasarkan pembagian kawasan adat, yakni kawasan kamase-masea dan kawasan kuassayya. Jenis situs dan fungsi dari masing-masing artefak di kawasan Kajang dijelaskan sebagai berikut :

\section{Fungsi Situs di Kawasan Kamase-masea (Kajang Dalam)}

Di kawasan kamase-masea hanya terdapat satu situs yakni Situs Tanah Toa. Kata "Tanah Toa" berarti "tanah tua" atau "tanah yang tertua." Fungsi sakral adalah berkaitan dengan adanya temuan yang dipergunakan sebagai media pemujaan kepada Tau Rie A'ra'na, seperti susunan batu temu gelang, batu pannurungang, kompleks makam dan ku'buru tunggalaka (makam tunggal). Sementara fungsi profan merefleksikan fungsi situs sebagai tempat berlangsungnya aktivitas keseharian dalam suatu permukiman atau situs habitasi. Bukti-bukti sebagai situs permukiman adalah adanya kelompok rumah berbentuk seragam, pagar batu, sumur sebagai sarana pendukung aktivitas rumah tangga, fragmen gerabah yang berfungsi sebagai sarana aktivitas keseharian, dan pembagian ruang atas petak-petak yang mengindikasikan sebagai tempat untuk membangun rumah, dan adanya pembagian kawasan hutan adat berdasarkan fungsinya.

Berdasarkan keragaman jenis dan fungsi temuan menunjukkan bahwa Situs Tanah Toa mempunyai empat fungsi yaitu: 1) Sebagai situs pemujaan atau situs upacara, 2) Situs pelantikan pemimpin di bidang spiritual, 3) Situs permukiman yang di dalamnya berlangsung berbagai aktivitas kehidupan baik yang bersifat profan maupun sakral, dan 4) Situs makam. Bahkan fungsi situs sebagai tempat bermukimnya masyarakat yang masih menjalankan secara ketat ajaran pasang yang diwariskan nenek moyang mereka, sebagai tempat bermukimnya Ammatoa yang berperan sebagai pemimpin keagamaan, sumber ketentuan adat, dan adanya pembagian fungsi ruang kawasan hutan adat, yaitu ruang yang berfungsi sosial dan befungsi sakral. Fungsi sosial sebagai simbol pemersatu masyarakat atau kesatuan adat, dan fungsi sakral sebagai tempat pelantikan Ammatoa dan pelaksanaan upacara adat berfungsi sebagai pusat pelaksanaan segala macam upacara ritual, menyebabkan masyarakatnya memandangnya sebagai suatu tempat yang sakral. Dengan demikian dalam kehidupan masyarakat, nampak dengan jelas batas antara ruang yang sakral dan 
ruang profan sangat jelas. Jenis upacara yang dilaksanakan berkaitan dengan keagamaan Patuntung seperti apparuntu' pangnganro (upacara doa) atau mange ri tau salama' ---ku'buru tunggalaka (pergi atau ziarah ke orang yang selamat). Upacara tersebut dilangsungkan sekali tiga atau tujuh tahun dan biasanya dilakukan bagi mereka yang telah berusia 40 tahun ke atas. Tempat dilakukan upacara ialah di hutan suci Tombolo yang disebut borong ilau' atau pa'rasangang ilau (hutan atau tempat di timur) di mana terdapat rumah mula (akapo atau batu pannurungang), kuburan sajang ( $k$ 'buru tunggalaka) atau tau salamaka atau tempat Bohe Amma (Ammatoa I menghilang), dan sebuah sumur suci. Upacara ini dipimpin langsung oleh Ammatoa.

Berdasarkan hasil wawancara dan perbandingan dengan data etnografi, yaitu berupa pola perkampungan tradisional yang masih berlangsung dalam masyarakat di sekitarnya, nampak bahwa letak bangunan sakral di dalam kawasan kamase-masea posisinya berada di tempat ketinggian, dikelilingi oleh kawasan hutan adat dan bangunan perumahan penduduk pada umumnya. Kawasan Situs Tanah Toa berfungsi sebagai pusat pemerintahan adat, dan juga sebagai tempat pelaksanaan upacara adat dan sebagai simbol pemersatu keluarga dan kesatuan adat.

Adanya batu pannurungang yang dianggap sebagai tempat turunnya manusia I (Bohe AmmalAmmatoa I) di Kajang, dan ku'buru tunggalaka (makam tunggal) sebagai tempat menghilangnya Bohe Amma/Ammatoa I, di dalam kawasan hutan adat menjadikan kawasan hutan adat ini diartikan sebagai tempat yang suci dan sakral/keramat pada Situs Tanah Toa dan di kawasan Kajang. Jenis upacara yang dilakukan pada situs ini ialah: 1) upacaraupacara yang berkenaan dengan kepemimpinan masyarakat adat seperti pengukuhan Ammatoa, 2) Upacara-upacara yang berkenaan dengan tanaman, terutama tanaman jagung dan padi: tatacara upacara berkenaan dengan bibit sampai penanaman dan penyimpanannya. Apabila padi sakit (garring) karena di makan tikus, maka Ammatoa memimpin suatu upacara doa yang disebut akaharu di hutan suci. Untuk mengusir penyakit hewan diadakan sesajian di atas tompong (tonggak bambu yang di atasnya berbentuk sangkar). Upacara a'borong galung (rapat sawah) untuk menentukan giliran berikutnya dalam pengolahan sawah, merupakan upacara pertemuan yang selalu dilakukan menjelang musim tanam berikutnya; 3) Upacara addingigngi yaitu upacara doa bersama di hutan suci untuk mendinginkan atau sebelum ada musibah. Upacara yang dilakukan meskipun secara besar-besaran tetapi tidak melibatkan banyak orang, sehingga tidak membutuhkan ruang yang luas untuk dapat menampung peserta upacara, dan terjangkau oleh banyak orang. Oleh karena itu, dicari tempat disekitar permukiman yang memungkinkan untuk hal tersebut. Adanya aturan adat yang menentukan dimana upacara pelantikan Ammatoa dan upacara a'nganro pa'ransangang ilau harus diadakan, karena kawasan Tanah Toa dianggap sama dengan struktur perkampungan yaitu sebagai perkampungan kecil (mikrokosmos) ketika berlangsungnya suatu upacara di tempat tersebut. Fungsi upacara di tempat tersebut, adalah: salah satu syarat agar arwah para pemimpin dapat "selamat" dan diterima oleh Tau Rie'a A'ra'na, serta keselamatan dan kesejahteraan bagi masyarakat, sebagai simbol ketentuan adat dan legitimasi kekuasaan bagi pimpinan adat tertinggi (Ammatoa), sebagai sarana untuk mempererat persaudaraan, sarana komunikasi antara pemimpin dengan Tau Rie A'ra'na, dan sebagai simbol kebersamaan dalam bentuk gotong royong.

Menurut orang Kajang, hutan adat tidak bisa diganggu gugat, karena merupakan amanah dan pusaka leluhur mereka. Hutan menurut pasang digolongkan menjadi tiga kategori, yaitu: 1) Hutan keramat (borong karama'), hutan ini tidak boleh dimanfaatkan dengan alasan apapun karena dianggap keramat, 2) Hutan produksi terbatas (borong battasayya), merupakan hutan yang isinya dapat dimanfaatkan secara terbatas untuk upacaraupacara adat saja, dan 3) Hutan tebangan (borong tattakang), merupakan hutan milik atau hutan yang pengelolaannya diserahkan kepada masyarakat, tetapi tetap dikontrol oleh pemangku adat Kajang atas suruhan Ammatoa. Sistem tata ruang hutan (fores mapping) di kawasan Kajang disesuaikan dengan aturan yang terdapat dalam pasang, yang berbunyi sebagai berikut:

Iyamintu boronga riada'a tabbage ruwai, borong tattakang nakulle niera nitabbang 
kajunna, naborong karama' nilaranga nitabbang sambarang.

Artinya:

Sesungguhnya hutan secara adat terbagi dua: hutan tebangan yang bisa ditebang dan hutan keramat yang dilarang untuk ditebang sembarangan kayunya.

Dengan dasar aturan pasang ini, pembagian wilayah hutan di Kajang meliputi: 1). Hutan di sebelah timur (borong ilau), terdiri atas Hutan Tombolo (Tanatoa II), Hutan Karanjang (Tanatoa III), dan Hutan Tode (Tanatoa IV), 2). Hutan di sebelah barat (borong iraja) terdiri atas Hutan Tupolo/Balannipa dan Parukku, Pa'lengkerang Uhea dan Pa'kombengan Doang (Tanatoa I), 3). Hutan produksi terbatas (borong batasayya), masih termasuk hutan Tanatoa I. III, dan IV, dan 4). Hutan tebangan (borong tattakang) di luar dari kedua bentuk hutan di atas.

Dari uraian di atas, fungsi dari masingmasing artefak yang terdapat di Situs Tanah Toa, maka Situs Tanah Toa dapat dikatakan sebagai situs Megalitik sekaligus situs Islam yang berlanjut dan digunakan hingga saat ini. Sebagai situs Megalitik, ditandai dengan adanya batu pannurungang, batu temu gelang, dan ku'buru' tunggalaka (makam tunggal) yang terletak didalam hutan keramat. Sebagai situs Islam ditandai dengan adanya kompleks makam dengan tidak menjadikan orientasi makam utara-selatan sebagai "penanda" makam Islam, sebab dari informasi yang diperoleh, dan kenyataan di lokasi penelitian memperlihatkan bahwa selain orientasi makam utara-selatan juga di terdapat makam dengan orientasi timurbarat didalam kompleks makam yang sama. Menguburkan mayat dengan orientasi makam timur-barat masih dilakukan hingga saat ini, meskipun yang di makamkan sudah menganut agama Islam.

\section{Fungsi Situs di Kawasan Kuassayya (Kajang Luar)}

Berdasarkan fungsi jenis temuan yang terdapat di setiap situs di kawasan kuassayya, maka penulis mengkategorikan situs di kawasan kuassayya sebagai situs Megalitik dan situs Islam. Situs Megalitik terdapat di Desa Mattonging (Situs Possi Tana), dan di Desa Bonto Biraeng (Situs Anrong Guru Lagoppo). Di kedua situs Megalitik tersebut terdapat artefak berupa batu temu gelang, batu datar (flat stone), batu pemujaan, batu berlubang, dolmen, batu pelantikan, batu bergores, menhir, batu dakon dan makam Rangka'na dan Bannenna sebagai makam pra-Islam. Sedangkan situs Islam terdapat di Desa Lembang Lohe (Situs Tonteng Daeng Mattarang), Kelurahan Tanah Jaya (Situs Dea Daeng Lita, Situs Karaeng Cidu Daeng Mattarang, Situs Boto Daeng Pabeta, Situs Tobo Daeng Marappo), Desa Lembanna (Situs Lembanna, Situs Janggo Tujarra, Situs Mattu Daeng Pahakang), Desa Tanah Eja (Situs To Salama' Rijallayya), Desa Lembang (Situs Kambangtia), Desa Lembang Lohe (Situs Puang Liong), dan di Desa Bonto Biraeng (Situs Karaeng Sangkala Lombok).

Situs Possi Tana merupakan situs Megalitik, mempunyai fungsi sebagai: 1). tempat pelantikan karaeng yang dianggap sebagai unsur pemerintah, 2). tempat melepas nasar dan 3). tempat melakukan upacara agnganro ri sapo (doa di rumah). Upacara ini diadakan bila terjadi musibah yang menyeluruh di bidang pertanian, demikian juga bila segala usaha di bidang pertanian mendatangkan hasil yang memuaskan maka diadakan pesta panen di sapo. Temuan berfungsi sebagai sarana dalam pelaksanaan upacara yang khusus ditujukan kepada Tau Rie'a A'ra'na dan Pu'Tamparang. Upacara yang dilakukan di Situs Possi Tana ini dipimpin oleh anrong. Berdasarkan perbandingan dengan pola perkampungan yang berada di luar kawasan Kajang , nampak bahwa letak bangunan sakral posisinya selalu berada di tempat ketinggian dan dikelilingi oleh bangunan rumah penduduk. Letak Situs Possi Tana berada di sebelah timur Kawasan Kajang dan lebih tinggi dari situs-situs lain, seperti Situs Anrong Guru Lagoppo, Situs Dea Daeng Lita, Situs Mattutu Daeng Pahakang dll. Hal ini sesuai dengan ketentuan ajaran pasang bahwa tempat berlangsungnya upacara berkaitan dengan upacara a'nganro pa'rasangang ilau harus selalu berada di sebelah timur. Sedangkan ketinggian selalu berkaitan dengan adanya anggapan bahwa tempat tersebut lebih sakral, terutama karena digunakan untuk jenis upacara penyembahan kepada Tau Rie' A'ra'na yang kedudukannya paling tinggi dalam rangkaian upacara.

Nama "Possi Tana" berasal dari kata "possi" artinya pusat dan "tana" artinya tanah/tempat. Dengan demikian, penamaan Possi Tana yang berarti pusat tanah atau pusat 
jagad merupakan penjelmaan penghormatan manusia terhadap bumi sebagai sumber segala kehidupan. Hal ini sesuai dengan salah satu fungsi temuan yang ada di tempat tersebut yaitu pagar batu yang oleh penduduk disebut Possi Tanayya. Jenis upacara yang dilakukan di tempat ini adalah upacara yang berkaitan dengan kesuburan dan kesejahteraan masyarakat yang melibatkan unsur pemerintah. Dahulu upacara dilakukan secara besar-besaran dengan melibatkan banyak orang sehingga membutuhkan tempat yang dapat menampung dan terjangkau oleh banyak orang. Oleh karena itu, dicari tempat di sekitar permukiman yang memungkinkan untuk kebutuhan tersebut. Fungsi upacara yang dilakukan di tempat tersebut, adalah sebagai simbol kesejahteraan dan keselamatan bagi keturunan, salah satu syarat bagi pimpinan adat limaya karaeng tallua untuk dilantik di Possi Tana, sebagai simbol status sosial dan legitimasi kekuasaan, sebagai sarana untuk mempererat tali persaudaraan, sarana komunikasi antara pemimpin dengan rakyatnya, dan sebagai simbol kebersamaan dalam bentuk gotong royong. Dengan demikian Situs Possi Tana selain tempat melaksanakan upacara pemujaan sebagai tanda ucapan syukur kepada para dewa yang telah memberikan kesejahteraan dan keselamatan hidup, juga berfungsi sebagai tempat pelantikan karaeng yang dianggap sebagai unsur pemerintah.

Situs Anrong Guru Lagoppo dapat dikategorikan hanya sebagai tempat untuk melaksanakan upacara pemujaan. Jenis upacara yang dilakukan pada situs ini adalah upacara yang bentuknya sederhana pada waktu-waktu tertentu seperti sehabis panen atau waktu-waktu luang lainnya dengan membawa sesajian untuk dipersembahkan kepada Tau Rie'a A'Ra'na. Tujuan upacara yang dilakukan adalah penyampaian rasa syukur kepada Tau Rie'a $A^{\prime} R a$ 'Na yang telah memberikan kesejahteraan dan keselamatan hidup, keberhasilan panen, dan terhindar dari bahaya wabah penyakit. Kata Anrong Guru Lagoppo berasal dari kata "anrong" (bahasa Makassar) berarti induk atau sumber. Namun ada pula yang mengartikan bahwa kata anrong berasal dari kata "onrong" (bahasa Bugis) yang berarti tempat. Apabila kata anrong (onrong) ditambahkan kata "guru" (pemberi amalan), maka akan berarti tempat orang meminta dan memohon sesuatu. Pengertian ini dapat diterima karena "anrong guru" merupakan gelar yang diberikan kepada salah satu pemangku adat dalam ada' limayya karaeng tallua. Adanya perubahan kata anrong menjadi onrong, dapat dimengerti oleh karena daerah Bonto Biraeng tempat beradanya Situs Anrong Guru Lagoppo merupakan daerah peralihan penggunaan bahasa Makassar dialek Konjo dengan bahasa Bugis.

Dari riwayat penamaan situs dapat diketahui bahwa Situs Anrong Guru Lagoppo bertujuan untuk pemenuhan kebutuhan akan religi. Dari segi fungsi, maka Situs Anrong Guru Lagoppo berperanan dalam memediasi kebutuhan religi masyarakatnya, yaitu sebagai wahana perantara antara komunitas manusia dengan roh atau dewa yang disembah. Hal ini sangat beralasan oleh karena pada masa itu masyarakat belum menganut agama Islam. Dalam perkembangan selanjutnya, fungsi dan peranan obyek ini bergeser, ketika agama Islam masuk di daerah tersebut. Masuknya agama ini tidak secara langsung membawa perubahan, terutama sekali dari segi perilaku atau kebiasaan-kebiasaan dari masa sebelumnya. Pergeseran fungsi terlihat pada opini dan asumsi masyarakat bahwa benda yang terdapat pada tempat (situs) itu memiliki kekuatan sehingga dianggap sebagai benda yang keramat, dan secara psikologis dapat mempengaruhi manusia. Pada tingkat inilah obyek tersebut mengalami perubahan sebagai obyek atau sarana untuk memohon dan meminta sesuatu yang berlangsung sampai sekarang, meskipun bagi mereka menganggap bahwa media tersebut hanya sebagai perantara.

Keberadaan situs Islam di kawasan kuassayya ditandai dengan adanya makammakam kuno yang terdapat di 13 kompleks makam. Keberadaan makam-makam kuno tersebut memperlihatkan akan adanya aspek sosial, aspek politik, aspek ideologi dan aspek teknologi yang telah berkembang dalam waktu yang cukup lama di kawasan kuassayya dan melahirkan kelompok masyarakat yang amat kompleks. Dari bentuk makam dan nisan terlihat adanya kesinambungan budaya antara budaya pra-Islam dengan budaya Islam di wilayah kuassayya ini. Tradisi lokal yang masih dipegang teguh oleh masyarakat masih berlangsung hingga sekarang. Hal tersebut tak bisa dipungkiri karena proses Islamisasi pada daerah Bulukumba mendapat kelonggaran oleh Datuk ri Tiro sehingga siklus hidup pra-Islam 
masih berlangsung (Sewang, 2005: 97). Keberlanjutan budaya antara budaya Megalitik dengan budaya Islam di kawasan kuassayya dapat dilihat antara lain pada prosesi pemakaman, orientasi makam, bentuk nisan dan jirat makam. Keberlanjutan budaya Megalitik ke budaya Islam nampaknya lebih condong ke budaya lokal yang telah berkembang di Kajang. Pemberian tanda berupa menhir pada masa prasejarah dan nisan pada masa Islam, secara prinsip mempunyai kesamaan, yaitu sebagai tanda adanya penguburan. Adanya kesamaan ini menimbulkan suatu pemanfaatan fungsi, terutama dari fungsi bentuk sebagai tanda kubur pada masa Islam (Wiyana, 2008: 311). Sehingga hal tersebut menghasilkan suatu dinamika budaya pada daerah Kajang. Menurut Rosmawati (2013) bahwa tampilan makam berkaitan erat dengan budaya setempat, terutama aspek sosial. Aspek-aspek sosial yang mempengaruhi wujud makam adalah status sosial, peranan semasa hidup, jenis kelamin dan umur.

Kebudayaan Islam di Sulawesi Selatan telah mengalami perkembangan dari masa ke masa. Pada awal Islamisasi abad 16 Masehi, tampilan makam dipengaruhi oleh budaya Melayu yang menekankan kesederhanaan sesuai dengan ajaran Islam. Kemudian abad 17 Masehi muncul budaya lokal yang telah berakulturasi dengan budaya Islam Melayu. Abad 18 Masehi budaya lokal semakin kuat dalam proses Islamisasi dengan menonjolkan unsur-unsur budayanya, dan abad 19 Masehi budaya lokal telah menjadi kebudayaan Islam di kawasan tersebut dengan menggunakan unsur-unsur budaya Megalitik yang kuat (Rosmawati, 2013: 469).

Proses masuknya Islam di Sulawesi Selatan mempengaruhi bentuk makam, orientasi makam, penggunaan nisan dan jirat serta hiasan pada makam. Seperti yang kita ketahui bahwa sebelum adanya agama Islam, telah ada kepercayaan-kepercayaan leluhur yang menjadi pegangan hidup masyarakat pada waktu itu. Begitu pula dengan kepercayaan yang melatarbelakangi penggunaan nisan dengan memiliki unsur lokal yang kuat. Unsur lokal berkembang pesat sebelum adanya agama Islam sehingga ketika Islam telah ada, masih terdapat budaya lokal yang berpadu dengan budaya Islam.
Unsur lokal yang dimaksud adalah penggunaan menhir sebagai nisan yang diadopsi dari kebudayaan sebelum Islam. Adanya peranan menhir yang meliputi kurun waktu cukup lama, sehingga tidak mengherankan jika terjadi perkembangan pada bentuk dan fungsi menhir itu sendiri (Sukendar dalam Wiyana, 2008: 311). Fungsi menhir sebelum adanya Islam adalah sebagai petanda, sedangkan pemberian tanda pada penguburan Islam merupakan salah satu sunnah. Sebagaimana hadits yang diriwayatkan Akhmad dan Muslim, "disunahkan memberi tanda kubur dengan batu atau tanda lain pada bagian kepala." Pemberian tanda berupa menhir pada masa prasejarah dan nisan pada masa Islam secara prinsip mempunyai kesamaan, yaitu sebagai tanda adanya penguburan (Wiyana, 2008: 311). Adanya kesamaan ini menimbulkan suatu pemanfaatan fungsi, yaitu sebagai tanda kubur meskipun mengalami perubahan bentuk, awalnya sederhana pada masa prasejarah kemudian diperhalus pada masa Islam.

Dalam perjalanannya, fenomena kebudayaan Islam telah mengalami perubahan dan perkembangan. Oleh karena itu, setiap kebudayaan di suatu daerah berbeda-beda dari zaman ke zaman. Perubahan tersebut terjadi karena adanya kontak dengan kebudayaan lain. Hubungan tersebut mengakibatkan terjadinya akulturasi antara kebudayaan pra-Islam dengan Islam (Rosmawati, 2013: 475). Tinggalan arkeologi Islam telah banyak terjadi percampuran budaya, baik budaya lama maupun budaya baru. Pada masa prasejarah terdapat tinggalan tradisi megalitik berupa menhir yang kemudian pada masa Islam mempengaruhi tinggalan arkeologi Islam. Menhir yang digunakan sebagai medium untuk memperingati orang yang telah mati, kemudian dijadikan sebagai petanda (nisan) bagi orang yang telah mati di masa Islam. Penggunaan menhir sebagai nisan tidak terlepas dari kebudayaan pra-Islam. Dalam prespektif kebudayaan, sebelum Islam masuk ke suatu daerah, telah lahir berbagai bentuk kepercayaan yang dalam praktek (Wiyana, 2008: 311). ritualnya memiliki perbedaan antara satu daerah dengan daerah lainnya. Pemahaman masyarakat terhadap suatu zat yang diyakini memelihara dan melindungi umat manusia juga tercermin melalui peristilahan seperti Dewata. Hal itu 
dimungkinkan karena ketika itu, pemahaman masyarakat tentang alam dan penciptanya sebatas pengetahuan dari pengalaman hidupnya dalam mengabdikan diri dengan alam. Tradisi pendirian bangunan megalitik selalu berdasarkan pada kepercayaan akan adanya hubungan antara yang hidup dengan yang mati, terutama kepercayaan akan adanya pengaruh kuat dari yang telah mati terhadap kesejahteraan masyarakat dan kesuburan tanaman (Soejono, 1993: 205). Dengan kata lain, pada tradisi megalitik mereka percaya akan adanya pengaruh dari orang yang telah mati terhadap yang masih hidup. Hal tersebut tidak jauh berbeda didalam pasang yang dianut oleh komunitas Ammatoa. Mereka percaya bahwa dengan melakukan amalan pasang di dunia maka ketika diakhirat akan mendapat sesuai dengan yang dilakukan. Sikap terhadap alam kehidupan sesudah mati yang mempercayai bahwa roh seseorang tidak lenyap begitu saja saat orang meninggal, melainkan mempunyai kehidupan di alamnya tersendiri sesudah meninggal.

Berdasarkan orientasi makam yang terdapat pada setiap situs di kawasan kuassayya, maka dibuat dua kategori situs makam yaitu; situs makam pra-Islam dan situs makam Islam. Keberadaan makam kuno dalam jumlah banyak memperlihatkan akan adanya aspek sosial, aspek politik, aspek ideologi, dan aspek teknologi yang telah berkembang dalam waktu yang cukup lama. Selain itu, makammakam kuno yang terdapat di kawasan Kajang memberikan gambaran terciptanya kelompok masyarakat yang amat kompleks.

Pada dasarnya penguburan merupakan salah satu wujud aktivitas manusia dalam merawat mayat segera setelah kematian terjadi. Dapat pula dikatakan merupakan salah satu kegiatan sosial manusia dalam memindahkan mayat dari lingkungan orang yang masih hidup ke lingkungan di mana mayat akan dimakamkan. Pelaksanaannya dilakukan secara terpola sesuai dengan pranata kelakuan tertentu serta didasarkan pada kebudayaan masyarakat pendukungnya, misalnya pada masyarakat yang berkebudayaan Islam dalam sistem perilaku penguburannya, tentunya mengikuti konsep dan tata cara penguburan Islam yang dicirikan oleh bentuk makam dengan orientasi utara selatan. Akan tetapi tidak jarang pula bentuk makam masih banyak diwarnai oleh konsep tradisi yang berkembang sebelumnya yakni pra Islam, sehingga nampak adanya dinamisasi budaya. Dinamisasi budaya di kawasan Kajang nampak dengan adanya bentuk makam Islam denngan tradisi pra Islam ditonjolkan, antara lain dapat dilihat pada bentuk nisan, orientasi makam, serta perilaku masyarakat terhadap makam.

Data makam kuno yang terdapat di situssitus di kawasan Kajang dalam pelaksanaannya, terlihat akan adanya wujud pengaruh konsepsi pra Islam yang berkembang dan berlanjut sampai sekarang, seperti yang nampak pada empat situs di kawasan Kajang yakni di Situs Ammatoa, Situs Possi Tana, Situs Tonteng Daeng Mattarang, dan di Situs Karaeng Sangkala Lombok. Di Situs Ammatoa, Situs Tonteng Daeng Mattarang, dan di Situs Karaeng Sangkala Lombok terdapat dua orientasi makam dalam kompleks makam, yakni orientasi utara selatan dan timur barat, sedangkan makam di Situs Possi Tana berorentasi timur barat. Lokasi keberadaan makam di empat situs tersebut terletak pada tempat ketinggian. Penempatan makam pada tempat ketinggian cenderung dipengaruhi oleh konsepsi yang berkembang sebelum datangnya pengaruh Islam. Konsep kepercayaan yang menganggap tempat yang lebih tinggi dari lokasi bermukim, selain sebagai tempat bersemayam arwah leluhur juga memudahkan roh si mati dalam memantau anak cucu mereka. Nampaknya dasar kepercayaan tersebut yang melatar belakangi penempatan bangunan makam pada tempat ketinggian sehingga nampak adanya penyesuaian konsep pra Islam dan konsep Islam. Perkembangan tradisi pra Islam di Indonesia dan Pasifik menunjukkan adanya kontinuitas dalam perkembangan serta mengadakan penyesuaian dengan arus budaya yang berkembang kemudian (Soejono, 1989: 227).

Dijadikannya kuburan sebagai kuburan keramat, dan pada waktu tertentu diadakan upacara ritual pada makam tersebut, secara tidak langsung mencerminkan adanya sistem organisasi politik. Orang yang dikubur dianggap telah berjasa pada masyarakat semasa hidupnya, sehingga cara untuk mengenang jasa mereka dengan cara melakukan upacara ritual pada tempat penguburannya. Aktivitas semacam ini masih sering terjadi pada makam tunggal (ku'buru' tunggalaka) di Situs Ammatoa, makam Rangka'na dan makam 
Bannenna di Situs Possi Tana, makam Karaeng Tonteng Daeng Mattarang, makam Tosalama Rijallayya, makam Sugi Daeng Manontong dan pada makam Karaeng Sangkala Lombok.

Kematian merupakan suatu keadaan yang tidak merubah kedudukan sosial seseorang dalam proses peralihan dari dunia nyata ke dunia arwah. Nampaknya konsep ini masih tetap dipertahankan pada bentuk makam. Bentuk makam masih memperlihatkan adanya variasi tipe yang menonjol. Sebagian makam dibuat dari susunan papan batu andesit dengan bentuk nisan tertata, sebagian dilengkapi hiasan. Sementara bentuk makam lainnya hanya dibuat dari batu-batu panjang dan ujungnya ditanam dalam bentuk sederhana. Meskipun dalam konsep Islam penguburan seperti ini tidak dianjurkan tetapi konsep dasar yang berkembang yakni konsep pra Islam merupakan unsur pokok dan tetap berpengaruh dalam prosesi pemakaman. Jadi telah terjadi sistem stratifikasi sosial yang sangat ketat dimana manusia dalam hidupnya memiliki derajat yang tinggi, maka bentuk makam mereka setelah mati harus pula mencerminkan derajatnya sewaktu masih hidup. Hal seperti ini masih tetap berlanjut sampai sekarang dan bahkan masih terdapat makam di kawasan Kajang dijadikan sebagai tempat pelaksanaan upacara ritual oleh masyarakat setempat.

\section{Ruang dalam Permukiman di Kawasan Kajang}

Berdasarkan letak temuan di setiap situs di kawasan Kajang, dan fungsi masingmasing temuan dari setiap situs, maka pembagian ruang permukiman di kawasan Kajang dapat dibagi sebagai berikut:

\section{Ruang Hunian}

Ruang hunian pada permukiman di kawasan Kajang terdapat di dua wilayah adat yakni di kawasan kamase-masea dan kawasan kuassayya. Ruang hunian di kedua kawasan adat tersebut ditandai dengan adanya temuan pagar batu, sumur, dan keramik (keramik lokal (gerabah) dan keramik asing), kompleks makam. Pagar batu berfungsi sebagai batas halaman rumah dengan jalan. Sebaran fragmen gerabah dapat dijumpai disetiap halaman rumah yang terdapat di dalam pagar batu (Situs Ammatoa), di Situs Possi Tanah. Kompleks makam ditemukan pada delapan tempat yang berbeda, yaitu terletak di bagian selatan, timur, dan barat permukiman. Makam yang terdapat di bagian selatan (kawasan kuassayya) disebut sebagai kompleks makam para bangsawan, begitu juga dengan keberadaan makam dibagian selatan disebut sebagai makam Rangka'na dan Bannenna (kawasan kuassayya). Sedangkan makam yang terdapat dibagian barat disebut kompleks makam Tanah Toa dan makam tunggalaka (makam tunggal) (kawasan kamasemasea). Ketiga lokasi makam di kawasan Kajang ini merupakan representasi dari pembagian perkampungan yang terdapat di kawasan Kajang berdasarkan pasang. Pembagian tersebut tercipta berdasarkan dari kebiasaan memakamkan seseorang disekitar huniannya.

Berdasarkan letak dari ketiga makam tersebut dan informasi yang diperoleh dari beberapa masyarakat bahwa di kawasan Kajang terdapat 3 penamaan tempat atau toponim hunian yang berbeda yaitu: Tanah Toa (Benteng), Possi Tana (Bongki), dan Tanah Lohea.

\section{Tanah Toa (Benteng)}

Tanah Toa terletak ditengah-tengah kawasan Kajang, yang dikelilingi oleh desadesa yang masih berada dalam wilayah Kecamatan Kajang yakni bagian utara berbatasan dengan Desa Batunilamung, bagian selatan berbatasan dengan Desa Bontobaji, di bagian barat berbatasan dengan Desa Pattiroang serta pada bagian timur berbatasan dengan Desa Malleleng. Selain itu, Desa Tanah Toa juga dibatasi oleh empat sungai kecil yang dijadikan batas alam untuk memisahkan kawasan adat berdasarkan fungsi dan hierarkinya. Keempat sungai tersebut yaitu; Sungai Limba di bagian timur, Sungai Doro di bagian barat, Sungai Tuli di bagian utara dan Sungai Sangkala di bagian barat. Keempat sungai inilah yang dijadikan pembatas kawasan adat yakni: kawasan kamase-masea disebut juga dengan istilah ilalang embayya dan kawasan kuassayya disebut juga dengan istilah ipantarang embayya. Kedua istilah ini digunakan oleh masyarakat untuk mendefenisikan keberadaan ekositemnya dengan segala karakteristik khas yang mereka miliki. 
Kawasan kamase-masea terutama di Dusun Benteng Desa Tanah Toa merupakan hunian masyarakat yang menganggap dirinya masih turunan tau kentarang (turunan Ammatoa). Umumnya masyarakat masih menganut ajaran patuntung, dan masih mengikuti ajaran pasang secara ketat. Di Tanah Toa (Dusun Benteng) ini terdapat temuan dengan fungsi sakral dan profan. Temuan yang berfungsi sakral adalah batu pannurungang, makam (ku'buru' tunggalaka dan kompleks makam), sumur (sumur tomanurung dan sumur jodoh), kawasan hutan. Temuan yang berfungsi profan adalah pagar batu, kelompok rumah dengan ciri tersendiri, fragmen keramik lokal (gerabah), kawasan hutan , dan sumur (sumur tunikeke, dan sumur bersebelahan). Sebaran fragmen gerabah ditemukan didalam pagar batu, sedangkan makam terdapat di dua lokasi yakni didalam hutan keramat yang berada dibagian barat permukiman (makam tunggal/ ku'buru' tunggalaka), dan di bagian selatan permukiman warga Dusun Benteng (Kompleks makam Tanah Toa). Makam tunggal (ku'buru' tunggalaka) merupakan makam Ammatoa 1 yang disebut Bohe Amma, sedang kompleks makam Tanah Toa merupakan kompleks makam masyarakat Dusun Benteng. Sumur terdapat di dua lokasi yakni dibagian barat didalam hutan keramat, dan dibagian utara sebelum permukiman warga.

\section{Possi Tana (Bongki)}

Possi Tana (Bongki) merupakan sebutan perkampungan yang berada pada bagian timur kawasan Kajang. Sebutan "Bongki" digunakan oleh masyarakat merujuk kepada artefak yang terkonsentrasi di atas bukit Bongki (lihat lampiran peta estimasi situs). Daerah permukiman/ hunian masyarakat berada dikaki bukit Bongki. Masyarakat yang menghuninya adalah masyarakat yang mengangap dirinya turunan gallarang (lihat lampiran struktur geneologis orang Kajang), mereka pada umumnya pejabat yang bertugas untuk membantu Ammatoa dalam berhubungan dengan masyarakat di luar wilayah kamasemasea. Bukti keberadaan hunian ditandai dengan temuan yang berfungsi sakral dan profan. Temuan berfungsi sakral ditandai dengan adanya makam Rangka'na dan Bannenna yang dianggap sebagai turunan bangsawan dari Luwu, batu temu gelang, dolmen, batu dakon dan batu bergores, batu datar, batu pelantikan, sumur yang digunakan oleh masyarakat untuk keperluan ritual, dan keramik (gerabah dan keramik asing). Keberadaan keramik asing di kawasan kuassayya menunjukkan bahwa masyarakat sekitarnya sudah mengadakan hubungan dengan masyarakat luar.

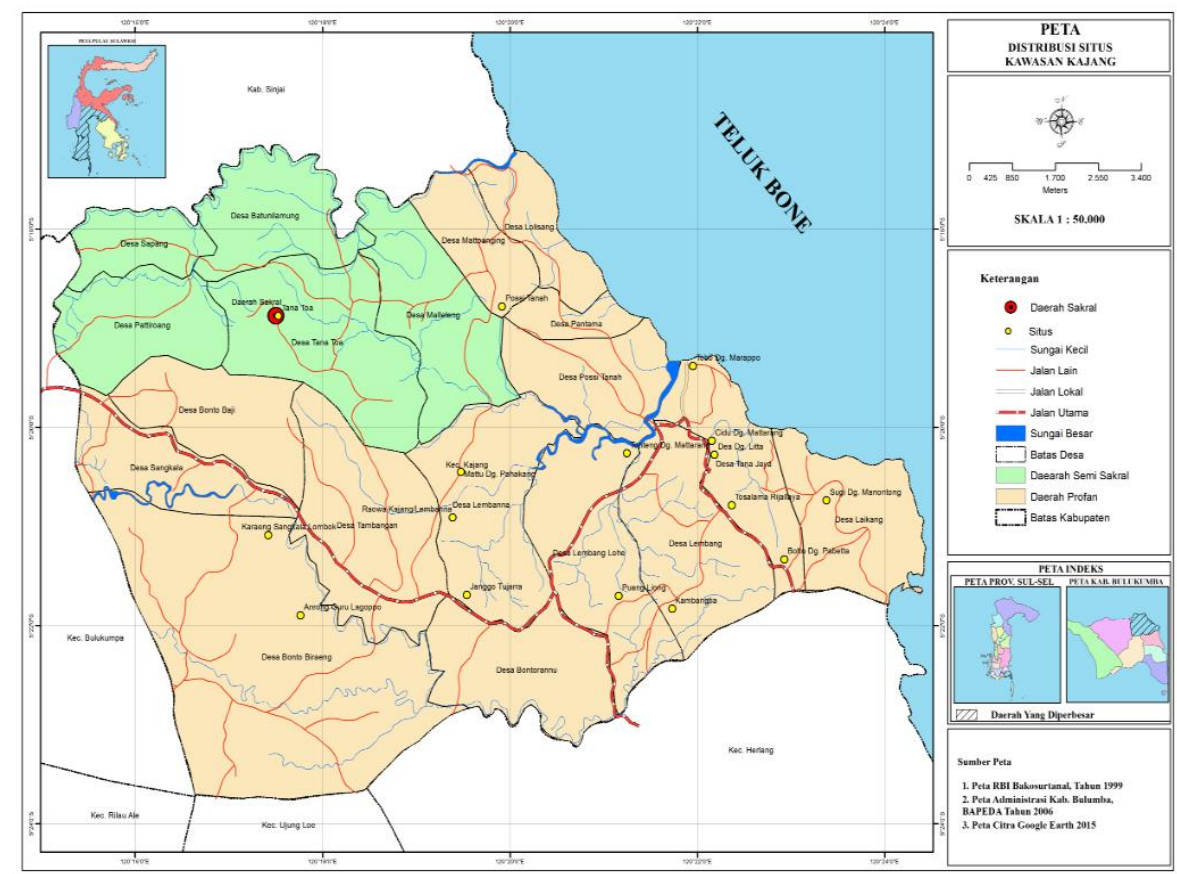

Gambar 2. Distribusi Situs Kawasan Kajang

(Sumber: Peta Bapeda Kab. Bulumba dimodifikasi oleh Penulis, 2016) 


\section{Tanah Lohea}

Sebutan Tanah Lohea digunakan untuk menyebut kawasan kuassayya terutama perkampungan yang terletak dibagian timur dan selatan kawasan Kajang. Masyarakat yang berdiam disini menganggap dirinya sebagai turunan bangsawan. Para bangsawan, dan turunannya dimakamkan disekitar huniannya. Kompleks makam terletak dibagian selatan kawasan Kajang, dan terdiri dari 11 komplek makam. Selain sebagai tempat hunian bangsawan, Tanah Lohea ini juga dianggap sebagai tempat hunian pembawa agama Islam di kawasan Kajang. Sebaran keramik asing ditemukan di empat lokasi situs. Data keramik asing dianggap sebagai salah satu indikasi bahwa suatu permukiman sudah melakukan interaksi dan kerjasama dengan dunia luar.

\section{Ruang Keagamaan}

Ruang keagamaan di kawasan Kajang, berada di tiga lokasi (Tanah Toa, Possi Tana, dan Anrong Guru Lagoppo) yakni:

1. Ruang keagamaan di Situs Tanah Toa berada di bagian barat, terletak di dalam kawasan hutan keramat. Pada area ini terdapat beberapa temuan arkeologi yang diperuntukkan untuk upacara pelantikan Ammatoa, yakni : batu pannurungang, batu temu gelang, dan ku'buru' tunggalaka (makam tunggal), yang dianggap sebagai makam Ammatoa 1 (Bohe Amma).

2. Ruang keagamaan di Situs Possi Tana (Bongki) berada pada bagian timur. Pada area ini terdapat beberapa temuan arkeologi yang difungsikan untuk upacara pelantikan pemangku adat yang dianggap sebagai unsur pemerintah, dan upacara pemujaan seperti: batu pemujaan, batu bergores, batu temu gelang, batu pelantikan, batu datar, batu berdiri dan makam Rangka'na dan Bannenna.

3. Ruang keagamaan di Situs Anrong Guru Lagoppo berada pada bagian barat. Pada area ini terdapat temuan arkeologi yang digunakan untuk upacara pemujaan seperti: menhir, dolmen, batu datar, dan batu bergores.

Dari uraian di atas, nampak bahwa di kawasan Kajang, terdapat tiga ruang keagamaan yang difungsikan sebagai tempat pelantikan dan tempat upacara. Ruang keagamaan ini terdiri dari :
1) Ruang pelantikan pemimpin adat di bidang spritual (pelantikan Ammatoa)

2) Ruang pelantikan pemangku adat di bidang pemerintahan sekaligus sebagai ruang upacara pemujaan.

3) Ruang pemujaan bagi masyarakat Kajang dan sekitarnya.

\section{KESIMPULAN}

Kawasan adat di Kajang terdiri dari kawasan kamase-masea dan kawasan kuassayya. Kedua kawasan adat tersebut dibatasi dengan hutan adat. Kedua status tersebut juga dapat dibedakan dari pola permukiman masyarakatnya. Di kawasan kamase-masea, aturan pasang diikuti secara ketat, pola permukimannya berkelompok (cluster pattern) dengan bentuk rumah yang seragam dan teratur. Penempatan rumah secara berkelompok mengarah pada ketinggian, arah hadap rumah menghadap ke arah barat, bangunan sakral berada pada tempat ketinggian yang dikelilingi oleh kawasan hutan adat, dan bangunan rumah penduduk, masyarakat tidak memperlihatkan pelapisan sosial. Di kawasan kuassayya, aturan pasang mulai tidak ditaati sepenuhnya, pola permukiman mulai menyebar mengikuti arah jalan, berbentuk memanjang dan berderet di sebelah menyebelah jalan, kaki bukit, dan dipinggir pantai dengan ciri-ciri masyarakat yang menunjukkan pelapisan sosial. Tidak ada orientasi khusus ke salah satu mata angin. Bangunan sakral berada di tempat ketinggian yang dikelilingi oleh bangunan rumah penduduk.

Apabila didasarkan pada hasil penafsiran bentuk dan fungsi budaya materinya, di Kawasan Kajang setidaknya dapat dibedakan antara ruang hunian dengan ruang keagamaan.

1. Ruang hunian yang terdiri atas tiga bagian dengan penamaan tempat yang berbeda yaitu Tanah Toa (Benteng), Possi Tana (Bongki), dan Tanah Lohea. Tanah Toa merupakan hunian masyarakat yang menganggap dirinya turunan tau kentarang (turunan Ammatoa), menganut patuntung, dan masih mengikuti ajaran pasang secara ketat. Possi Tana (Bongki), merupakan sebutan bagi permukiman yang berada pada bagian timur kawasan Kajang. Masyarakat yang menghuninya adalah masyarakat yang menganggap dirinya sebagai turunan gallarang, mereka pada umumnya adalah 
pejabat yang bertugas membantu Ammatoa dalam hal berhubungan dengan masyarakat di luar Dusun Benteng. Tanah Lohea, yang penghuninya menganggap dirinya turunan bangsawan. Di sini juga tempat hunian para pembawa agama Islam di kawasan Kajang.

2. Ruang keagamaan, berada di tiga lokasi situs, yakni di Situs Tanah Toa, Situs Possi Tana (Bongki), dan Situs Anrong Guru Lagoppo. Ruang keagamaan terdiri dari ruang pelantikan pemimpin adat dibidang spritual (pelantikan Ammatoa), ruang pelantikan pemimpin di bidang pemerintahan sekaligus sebagai ruang upacara pemujaan, dan ruang pemujaan bagi masyarakat Kajang dan sekitarnya.

\section{Saran}

1. Penelitian tentang kawasan Kajang diharapkan dapat menambah wawasan tentang kawasan permukiman tradisional yang tetap mempertahankan budaya mereka. Tradisi-tradisi yang mereka warisi dari leluhur mereka sangat kaya dan menarik, terlebih setelah terjadi akulturasi dengan kebudayaan dan kepercayaan setempat, sehingga apa yang didengar adalah sesuatu yang unik dan menarik. Sehubungan dengan itu penulis menyarankan agar dilakukan penelitian tentang beragam tradisi yang masih dilakukan oleh masyarakat setempat, namun hingga kini tradisi tersebut belum banyak terekam. Modernisasi yang terus berlangsung di kawasan itu dikawatirkan akan segera menghilangkan tradisi dan kearifan lokal yang ada di sana. Padahal tradisi dan kearifan lokal tersebut pasti akan sangat berguna bagi kajian tentang kebudayaan.

2. Di kawasan Kajang terdapat banyak tinggalan budaya materi, hal ini dapat memberi informasi terkait dengan tinggalantinggalan budaya pada masa lampau, baik dilihat dari bentuk bangunan, pola tata ruang kawasan, dan variasi pada makam. Berkembangnya zaman tidak membuat pengaturan tata ruang kawasan mengalami perubahan, terutama di wilayah adat kamase-masea. Hal ini dapat dilihat pada bentuk pola permukiman mereka yang masih mengikuti konsep yang berasal dari tradisi lisan mereka yakni pasang. Dengan semakin seringnya interaksi orang Kajang dengan orang luar, salah satu motivasi mereka adalah modernisasi. Untuk itu, perlu kiranya diteliti sejauh mana modernisasi mempengaruhi perilaku mereka. Bagaimana menerima modernisasi tanpa meninggalkan ajaran pasang. Kemungkinan di masa datang kawasan Kajang terutama di wilayah kamase-masea sulit untuk bertahan. Penulis berharap tumbuhnya kesadaran untuk mengembangkan kawasan Kajang sebagai kawasan arkeologi. Kebenaran asumsi perlu diteliti tentang pertanggalan, dan mendapat perhatian lebih lanjut dari instansi yang terkait.

\section{Ucapan Terima Kasih}

Ucapan terima kasih penulis sampaikan kepada Pembimbing Utama penulis Prof. Dr. Sumijati Atmosudiro dan Pembimbing Pendamping DR. Daud Aris Tanudirjo, M.A. atas bantuannya selama penyusunan disertasi berjudul 'Tata Ruang Permukiman Tradisional To Kajang Di Kabupaten Bulukumba Propinsi Sulawesi Selatan: Kajian Sistem Sosial dan Nilai Budaya.'

\section{$* * * * *$}

\section{DAFTAR PUSTAKA}

Ahimsa-Putra, Heddy Shri. (1995). "Arkeologi Pemukiman, Titik Strategis dan beberapa paradigma”. Berkala Arkeologi Tahun XV. Edisi Khusus balai Arkeologi Yogyakarta.

Butzer, Karl W. (1982). Archaeology as Human Ecology: Method and Theory for Contextual Aproach. Cambridge: Cambridge University Press.

Catanese, Anthony J and James C. Snyder. (1986). Pengantar Perencanaan Kota. Alih Bahasa: Susongko. Jakarta: Erlangga.

Erawati, Erni. (2016). "Tata Ruang Permukiman Tradisional To Kajang di Kabupaten Bulukumba Propinsi Sulawesi Selatan: Kajian Sistem Sosial dan Nilai Budaya." Disertasi. Yogyakarta: Universitas Gadjah Mada.

Fagan, M. Brian. (1985). In The Beginning An Introduction To Archaeology. Boston: Brow and Company.

Geldern, R. von Heine. (1945). "Prehistoric Research in the Netherland Indies". Science and Scientist in the Netherlands Indies. New York: Board for the Netherland Indies, Surinam and Curaçao. 
Heekeren, H.R. van. (1972). The Stone Age of Indonesia. The Haque-Martinus Nijhoff.

Katu, Mas Alim. (2008). Kearifan Manusia Kajang. Pustaka Refleksi: Makassar.

Koentjaraningrat. (1987). Sejarah Teori Antropologi 1. Jakarta: Universitas Indonesia Press.

Rapoport, Amos. (1986). "Asal Usul Budaya Pemukiman." Pengantar Perencanaan Kota. Terj. Susongko. Jakarta: Erlangga.

Renfrew, Colin \& Paul Bahn. (1996). Archaeology, Theories, Method and Practice. Second Edition. R.R. Donnelley and Sons company: United States of America.

Rouse, Irving. (1972). "Settlement Patterns in Archaeology", dalam P.J. Ucko, Ruth Tringham dan G.W. Dimbleby. Man, Settlement and Urbanism: pp. 95-107. England: Duckworth.

Rosmawati. (2013). "Perkembangan Tamadun Islam di Sulawesi Selatan, Indonesia: Dari Perspektif Arkeologi dan Sejarah." Disertasi. Pulau Penang: University Sains Malaysia.

Rossler, M. (1990). "Striving for modesty; Fundamentals of the religion and social organization of the Makassarese Patuntung. In: Bijdragen tot de Taal-, Land- en Volkenkunde 146 (1990), no: 2/3, Leiden, 289324.

Sewang, Ahmad. (2005). Islamisasi Kerajaan Gowa (Abad XVI sampai Abad XVII). Jakarta: Yayasan Obor Indonesia.

Sharer, Robert J. dan Wendy Ashmore. (1979). Fundamentals of Archaeology. California: Benjamin/ Cummings Publishing Company, Inc.

Soejono, R.P. (1976). "Tinjauan Tentang Pengkerangkaan Prasejarah Indonesia." Aspekaspek Arkeologi Indonesia No.5. Jakarta: P4N.

Soejono, R.P. (1977). "Sistem-Sistem Penguburan pada Akhir Masa Prasejarah di Bali.” Disertasi. Jakarta: Universitas Indonesia.

Soejono, R.P. (ed). (1993). Sejarah Nasional Indonesia 1. Departemen Pendidikan dan Kebudayaan Republik Indonesia. Jakarta: Balai Pustaka.

Thomas, D.H. dan R.L. Bettinqer. (1979). "Prehistoric Pinon Ecotone Settlements of The Upper Reese River Valley, Central Nevada". Antrhropological Papers of The American Museum of Natural History 53: pp. 263-366.

Hoop, van Der. (1932). Megalithic Remains in South Sumatera. Translated by W. Shirlaw, Zutphen. W.J. Thieme \& Cie.

Heekeren, H.R. van. (1958). The Bronze-Iron Age of Indonesia. Verhandelingen van Het Koninklijk Institut voor Taal-Landen Volkendunde. Dell XXII. S, Gravenhage.
Heekeren, H.R. van. (1972). The Stone Age of Indonesia. The Haque- Martinus Nijhoff.

Willey, Gordon R. (1953). Prehistoric Settlement Patterns in the Viru Valley. Bulletin 155. Washigton: Bureau of American Ethnology.

Wiseman. Rob. (2016). "Social Distance in Settled Comminities the Conceptual Metaphor, Social Distance is Physical Distance, in Action. Journal of Archaeological Method and Theory. Springer Verlag.

Wiyana, Budi. (2008). "Dari Menhir Ke Nisan, Suatu Dinamika Budaya". Dalam Pertemuan Ilmiah Arkeologi ke IX. Jakarta: Ikatan Ahli Arkeologi Indonesia. 